\title{
Isolation and Characterization of Novel Pantoea stewartii subsp. indologenes Strains Exhibiting Center Rot in Onion
}

Spencer Stumpf, Department of Plant Pathology, Coastal Plain Experiment Station, University of Georgia, Tifton 31793; Brian Kvitko, Department of Plant Pathology, University of Georgia, Athens 30602; and Ron Gitaitis and Bhabesh Dutta, ${ }^{\dagger}$ Department of Plant Pathology, Coastal Plain Experiment Station, University of Georgia, Tifton

\begin{abstract}
Center rot of onion is an economically important disease caused by three Pantoea spp.: Pantoea ananatis, P. agglomerans, and P. allii. Symptoms caused by these three species are similar and include white streaking and necrosis of foliage; and, in some cases, the bacterium may enter the bulb, causing liquefaction and rot of bulb scales. Two bacterial strains were isolated from onion expressing symptoms indicative of center rot from two different outbreaks in Toombs County, GA in 2003 (PNA 03-3) and 2014 (PNA 14-12). These strains were initially identified as $P$. ananatis based on physiological and specific polymerase chain reaction (PCR) assays; however, further 16S ribosomal RNA (rRNA) and multilocus sequence analysis showed that the strains were more closely related to $P$. stewartii subsp. stewartii and $P$. stewartii subsp. indologenes. Further characterization using phylogenetic analysis, a $P$. stewartii subsp. indologenes-specific PCR assay, indole test, and pathogenicity on onion and pearl millet were conducted. Phylogenetic analyses (16S

rRNA and $a t p D, g y B$, infB, and $r p o B$ genes) revealed that these strains formed a distinct cluster with the type strains of $P$. stewartii subsp. indologenes LMG $2632^{\mathrm{T}}$ and $P$. stewartii subsp. stewartii LMG $2715^{\mathrm{T}}$ separate from $P$. ananatis, $P$. agglomerans, and $P$. allii. Furthermore, onion strains were amplified with the $P$. stewartii subsp. indologenes-specific PCR assay. The pathogenicity assays with onion strains showed that they were pathogenic on onion and pearl millet, a known host of $P$. stewartii subsp. indologenes. However, the type strain of $P$. stewartii subsp. indologenes LMG $2632^{\mathrm{T}}$ was pathogenic only on pearl millet but not on onion. These results suggest that the onion strains PNA 03-3 and PNA 14-12 can potentially be novel $P$. stewartii subsp. indologenes strains capable of producing symptoms on onion. Hence, we recommend the inclusion of $P$. stewartii subsp. indologenes as the fourth member in the center rot complex of onion, along with $P$. ananatis, $P$. agglomerans, and $P$. allii.
\end{abstract}

Center rot of onion is caused by three known Pantoea spp.; namely, Pantoea ananatis, $P$. agglomerans, and P. allii (Brady et al. 2011; Edens et al. 2006; Gitaitis and Gay 1997; Hattingh and Walters 1981). P. ananatis was first reported in Georgia in 1997 from symptomatic onion foliage (Gitaitis and Gay 1997). Although $P$. agglomerans was associated with center rot of onion in South Africa in 1981, the bacterium was not identified as a causal agent of center rot in Georgia until 2006 (Edens et al. 2006; Hattingh and Walters 1981). This was the first report of the bacterium causing this disease in the United States (Edens et al. 2006).

$P$. allii was identified as the third member in Pantoea spp. complex causing center rot of onion (Brady et al. 2011). This bacterium was identified from infested onion plant and seed in Georgia (Brady et al. 2011). Initially, the bacterial strains pathogenic on onion were tentatively identified as members of the genus Pantoea based on phenotypic tests. However, after further genotypic and phenotypic characterization, including sequencing of $16 \mathrm{~S}$ ribosomal RNA (rRNA) and housekeeping genes (gyrB, rpoB, infB, and $a t p D)$, DNA-DNA hybridization, amplified fragment length polymorphism, and substrate utilization tests, the strains were identified as a novel species of Pantoea named $P$. allii, distinct from other known species (Brady et al. 2011).

Disease symptoms on foliage and onion bulbs caused by three Pantoea spp. are similar (Gitaitis et al. 2002; Walcott et al. 2002). Symptoms include white streaking along the length of the leaf with water soaked-margins. These streaks turn necrotic and appear blighted as the disease progresses. In severe cases, the entire plant may wilt with necrotic foliage. The bacterium may also invade bulb tissues, which can often result in opening avenues for secondary infections (Carr

${ }^{\dagger}$ Corresponding author: B. Dutta; E-mail: bhabesh@uga.edu

*The $\boldsymbol{e}$-Xtra logo stands for "electronic extra" and indicates that one supplementary figure is published online.

Accepted for publication 20 October 2017.

() 2018 The American Phytopathological Society et al. 2013). The invasion of secondary infections can result in liquefaction and rotting of tissue in storage. If conditions are ideal for disease, this pathogen can cause significant economic losses (Walcott et al. 2002).

Strains PNA 03-3 (2003) and PNA 14-12 (2014), isolated from onion foliage from two separate center rot outbreaks in Toombs County, GA, were utilized in this study. The study was aimed at deciphering genotypic relatedness of $P$. ananatis strains in Georgia using various methods, including multilocus sequence analysis (MLSA) and repetitive extragenic palindrome polymerase chain reaction (PCR). Although these strains were initially diagnosed as $P$. ananatis using phenotypic and PCR-based assays, they did not cluster with known $P$. ananatis strains (97-1 and LMG $2665^{\mathrm{T}}$ ) or with other center-rot-causing Pantoea spp. such as P. allii (LMG $24248^{\mathrm{T}}$ ) and $P$. agglomerans (06-1 and LMG $1286^{\mathrm{T}}$ ) strains when $16 \mathrm{~S}$ rRNA and four highly conserved housekeeping genes (atpD, gyrB, infB, and $r p o B$ ) were analyzed. Interestingly, the sequences of abovementioned genes exhibited $>99 \%$ similarity to $P$. stewartii subsp. indologenes and $P$. stewartii subsp. stewartii.

$P$. stewartii subsp. indologenes is known to cause leafspot on foxtail millet (Setaria italica) and pearl millet (Pennisetum americanum), while $P$. stewartii subsp. stewartii causes Stewart's wilt of corn (Mergaert et al. 1993). None of these P. stewartii spp. has been reported to cause disease on onion. $P$. stewartii subsp. stewartii is unable to utilize indole, whereas $P$. stewartii subsp. indologenes exhibits positive indole production. This assay has been a reliable method to differentiate these subspecies. However, it is difficult to differentiate $P$. ananatis and $P$. stewartii subsp. indologenes because both species exhibit many of the same phenotypic characteristics, such as being positive for indole production (Mergaert et al. 1993). In addition, published $P$. ananatis-specific primers cannot differentiate $P$. ananatis from $P$. stewartii (Gitaitis et al. 2002). In this article, we report the inclusion of $P$. stewartii subsp. indologenes as the fourth member in the center rot complex of onion. Multiple genotypic and phenotypic assays were utilized to confirm the identity and characterization of the bacterial pathogen, including sequence analysis of $16 \mathrm{~S}$ rRNA and housekeeping genes, species-specific $\mathrm{PCR}$, indole test, and pathogenicity on pearl millet and onion. 


\section{Materials and Methods}

Bacterial strains. Two strains investigated in this study, PNA 03-3 and PNA 14-12, were isolated from symptomatic onion foliage in Georgia in 2003 and 2014, respectively. These strains were stored in sterile $15 \%$ aqueous glycerol solution at $-80^{\circ} \mathrm{C}$. The strains were tentatively identified as $P$. ananatis by their morphological and physiological characteristics such as gram-negative, facultative anaerobic, positive for indole production, and negative for nitrate reductase and phenylalanine deaminase. Furthermore, confirmation was achieved by amplifying a 398-bp fragment using $P$. ananatis species-specific primers (Gitaitis et al. 2002). Additional strains used in this study are outlined in Table 1.

16S rRNA amplification and sequencing. Bacterial suspensions were grown overnight in nutrient broth following transfer of single colonies of each strain from 48-h old cultures on nutrient agar (NA) medium. The nutrient broth was shaken overnight on a rotary shaker (Inova; New Brunswick Scientific, Edison, NJ) at $150 \mathrm{rpm}$. After incubation, $1.8 \mathrm{ml}$ of bacterial suspension was used for genomic DNA extraction using an UltraClean Microbial DNA Kit (MO BIO, Carlsbad, CA) according to the manufacturer's instructions. DNA was quantified on a NanoDrop 1000 spectrophotometer (Thermo Scientific, Wilmington, DE) and 50 ng of genomic DNA was used for PCR. Amplifications were carried out in $50 \mu$ of a PCR master mix with the 16S rRNA primer pair (Table 2), as outlined by Weisburg et al. (1991). PCR products were subjected to gel electrophoresis in Tris-acetate-EDTA buffer on a $1.5 \%$ agarose gel at $100 \mathrm{~V}$ for $45 \mathrm{~min}$. Positive reactions were purified with a QIAquick PCR Purification Kit (Qiagen, Valencia, CA), according to the manufacturer's instructions, and were outsourced for sequencing (Eurofins, Louisville, KY).

MLSA. In addition to amplification of the $16 \mathrm{~S}$ gene, four housekeeping genes were amplified $(a t p D, g y B$, inf $B$, and $r p o B)$ (Table 2)

Table 1. Strains used in this study for genetic analysis and pathogenicity assays

\begin{tabular}{|c|c|c|c|}
\hline Strain name ${ }^{a}$ & Host & Place of isolation & Year of isolation \\
\hline Erwinia amylovora CFBP 1430 & Hawthorn & France & 1972 \\
\hline Pantoea agglomerans LMG $1286^{\mathrm{T}}$ & Human & Zimbabwe & 1888 \\
\hline P. agglomerans $06-1$ & Onion & Georgia, United States & 2006 \\
\hline P. allii LMG $24248^{\mathrm{T}}$ & Onion seed & South Africa & 2008 \\
\hline P. ananatis LMG $2665^{\mathrm{T}}$ & Pineapple & Brazil & 1965 \\
\hline P. ananatis $97-1$ & Onion & Georgia, United States & 1997 \\
\hline PNA 03-3 & Onion & Georgia, United States & 2003 \\
\hline PNA $14-12$ & Onion & Georgia, United States & 2014 \\
\hline P. stewartii subsp. indologenes LMG 2630 & Guar gum & Unknown & 1966 \\
\hline P. stewartii subsp. indologenes $\mathrm{LMG} 2632^{\mathrm{T}}$ & Foxtail Millet & India & 1960 \\
\hline P. stewartii subsp. indologenes LMG 2671 & Pineapple & Hawaii & 1966 \\
\hline P. stewartii subsp. indologenes CFBP 3517 & Foxtail Millet & India & Unknown \\
\hline P. stewartii subsp. indologenes CFBP 3614 & Foxtail Millet & India & 1960 \\
\hline P. stewartii subsp. stewartii GSPB 2626 & Corn & United States & Unknown \\
\hline P. stewartii subsp. stewartii LMG 2713 & Corn & United States & 1963 \\
\hline P. stewartii subsp. stewartii LMG $2715^{\mathrm{T}}$ & Corn & United States & 1970 \\
\hline P. stewartii subsp. stewartii LMG 2718 & Corn & United States & Unknown \\
\hline P. stewartii subsp. stewartii PSS 90-1 & Corn & United States & 1990 \\
\hline P. stewartii subsp. stewartii DS203 & Corn & United States & 2003 \\
\hline
\end{tabular}

a Superscript " $T$ " indicates type strain.

Table 2. List of primers used in this study

\begin{tabular}{|c|c|c|c|}
\hline Gene & Primer name & Primer sequence & References \\
\hline \multirow[t]{2}{*}{ 16S ribosomal RNA } & $\mathrm{fd} 1$ & 5'AGAGTTTGATCCTGGCTCAG-3' & Weisburg et al. 1991 \\
\hline & rd1 & 5'-AAGGAGGTGATCCAGCC-3' & \\
\hline \multirow[t]{2}{*}{$\operatorname{atpD}$} & atpD 01-F & 5'-RTAATYGGMGCSGTRGTNGAYGT-3' & Brady et al. 2008 \\
\hline & atpD 02-R & 5'-TCATCCGCMGGWACRTAWAYNGCCTG-3' & $\ldots$ \\
\hline \multirow[t]{2}{*}{ Sequencing primer } & atpD 03-F & 5'-TGCTGGAAGTKCAGCARCAG-3' & Brady et al. 2008 \\
\hline & atpD 04-R & 5'-CCMAGYARTGCGGATACTTC-3' & ... \\
\hline \multirow[t]{2}{*}{$\operatorname{gyr} B$} & gyrB 01-F & 5'-TAARTTYGAYGAYAACTCYTAYAAAGT-3' & Brady et al. 2008 \\
\hline & gyrB $02-\mathrm{R}$ & 5'-CMCCYTCCACCARGTAMAGTT-3' & \\
\hline \multirow{2}{*}{ Sequencing primer } & gyrB 07-F & 5'-GTVCGTTTCTGGCCVAG-3' & Brady et al. 2008 \\
\hline & gyrB $08-\mathrm{R}$ & 5'-CTTTACGRCGKGTCATWTCAC-3' & \\
\hline \multirow[t]{2}{*}{$\inf B$} & infB 01-F & 5'-ATYATGGGHCAYGTHGAYCA-3' & Brady et al. 2008 \\
\hline & infB 02-R & 5'-ACKGAGTARTAACGCAGATCCA-3' & $\ldots$ \\
\hline \multirow[t]{2}{*}{ Sequencing primer } & infB 03-F & 5'-ACGGBATGATYACSTTCCTGG-3' & Brady et al. 2008 \\
\hline & infB 04-R & 5'-AGYTTAGATTTCTGCTGACG-3' & $\ldots$ \\
\hline \multirow[t]{2}{*}{ rров } & rpoB CM7-F & 5'AACCAGTTCCGCGTTGGCCTG-3' & Brady et al. 2008 \\
\hline & rpoB CM31b-R & 5'-CCTGAACAACACGCTCGGA-3' & $\ldots$ \\
\hline \multirow[t]{3}{*}{ Sequencing primer } & rpoB CM81-F & 5'-CAGTTCCGCGTTGGCCTG-3' & Brady et al. 2008 \\
\hline & rpoB CM81b-F & 5'-TGATCAACGCCAAGCC-3' & $\ldots$ \\
\hline & rpoB CM32b-R & 5'-CGGACCGGCCTGACGTTGCAT-3' & $\ldots$ \\
\hline \multirow[t]{2}{*}{ galE } & 3614galE & 5'-CGACCTGTTTGCCTCTCACC-3' & Gehring et al. 2014 \\
\hline & 3614galEc & 5'-CATCAGCTTGGAGGTGCCG-3' & $\ldots$ \\
\hline \multirow[t]{2}{*}{$\operatorname{rec} A$} & $3614 \mathrm{recA}$ & 5'-TGACGCTGCAGGTGATTGCC-3' & Gehring et al. 2014 \\
\hline & $3614 \mathrm{recAc}$ & 5'-TCAGTGCGTTACCGCCGGTA-3' & $\ldots$ \\
\hline
\end{tabular}


and concatenated to produce a 2,260-bp fragment. Each PCR was performed in a $50-\mu l$ reaction consisting of $10 \mu$ l of $5 \times$ PCR buffer, $0.2 \mathrm{mM}$ dNTP, $0.2 \mu \mathrm{M}$ each primer, $1.25 \mathrm{U}$ of HotStart Taq Polymerase (Qiagen), and template DNA at $50 \mathrm{ng} / \mu \mathrm{l}$. Amplification conditions included denaturation at $95^{\circ} \mathrm{C}$ for $5 \mathrm{~min} ; 3$ cycles of denaturation at $95^{\circ} \mathrm{C}$, annealing at $55^{\circ} \mathrm{C}$ for $2 \mathrm{~min} 15 \mathrm{~s}$, and elongation at $72^{\circ} \mathrm{C}$ for $1 \mathrm{~min} 15 \mathrm{~s}$; followed by 30 cycles of denaturation at $95^{\circ} \mathrm{C}$ for $35 \mathrm{~s}$, annealing at $55^{\circ} \mathrm{C}$ for $1 \mathrm{~min} 15 \mathrm{~s}$, and elongation at $72^{\circ} \mathrm{C}$ for $1 \mathrm{~min}$ $15 \mathrm{~s}$; and a final step of $7 \mathrm{~min}$ of elongation at $72^{\circ} \mathrm{C}$ (Brady et al. 2008). Amplicons were confirmed using gel electrophoresis and purified as described above. The purified amplicons were outsourced for sequencing. The list of PCR amplification and sequencing primers for each housekeeping genes is provided in Table 2. All sequences of MLSA and 16S rRNA were deposited in the GenBank database under accession numbers MF771244 to MF771259.

Phylogenetic analysis of sequencing data. Sequences were manually trimmed based on peak quality of forward and reverse chromatograms in Geneious 8.1.8 (Biomatters, Auckland, New Zealand) and were aligned using MUSCLE ( https://www.ebi.ac.uk/Tools/msa/muscle/). The trimmed and aligned $16 \mathrm{~S}$ rRNA sequences $(667 \mathrm{bp}$ ) were used to generate a maximum-likelihood (ML) tree based on the Tamura-Nei model of MEGA 6.06, with bootstrapping repetitions of 1,000. Likewise, a phylogenetic tree was generated using trimmed and concatenated sequences of the four housekeeping genes: atpD (657 bp), gyrB (579 bp), infB (615 bp), and rpoB (409 bp).

Indole test. Single colonies of bacterial strains $P$. stewartii subsp. stewartii $\mathrm{LMG} 2715^{\mathrm{T}}$ and $P$. stewartii subsp. indologenes type strains LMG 2632 ${ }^{\mathrm{T}}$, along with PNA 03-3, and PNA 14-12, from 48-h-old NA plates were restreaked onto tryptic soy agar amended with $1 \%$ DL-tryptophan (Sigma Aldrich, St. Louis). P. stewartii subsp. stewartii
LMG $2715^{\mathrm{T}}$ and $P$. stewartii subsp. indologenes type strains LMG $2632^{\mathrm{T}}$ served as negative and positive controls, respectively. After incubation for $12 \mathrm{~h}$ at $28^{\circ} \mathrm{C}$, single colonies were streaked onto commercially available DrySlide indole cards (Becton, Dickinson and Company, Sparks, MD). A positive reaction for indole production was indicated by the presence of purple color on the card when test cultures were applied. The assay was repeated three times.

P. stewartii subsp. indologenes-specific PCR. Primers used in this PCR assay (Table 2) were from Gehring et al. (2014) and were specific to $P$. stewartii subsp. indologenes based on single-nucleotide polymorphisms within recA and galE protein-coding genes. Genomic DNA from $P$. stewartii subsp. indologenes LMG $2632^{\mathrm{T}}$, P. stewartii subsp. stewartii LMG 2715 , PSS 90-1, PSS DS203, PNA 03-3, and PNA 14-12 were included in this assay. The PCR cycle for recA and galE primer pairs included a two-step series: initial denaturation at $94^{\circ} \mathrm{C}$ for $2 \mathrm{~min} ; 10$ cycles of a denaturation step at $94^{\circ} \mathrm{C}$ for $20 \mathrm{~s}$, annealing at $68^{\circ} \mathrm{C}$ for $30 \mathrm{~s}$, and elongation at $72^{\circ} \mathrm{C}$ for $30 \mathrm{~s} ; 20$ cycles of denaturation step at $94^{\circ} \mathrm{C}$ for $20 \mathrm{~s}$, annealing at $63^{\circ} \mathrm{C}$ for $30 \mathrm{~s}$, and elongation at $72^{\circ} \mathrm{C}$ for $30 \mathrm{~s}$; and a final elongation step at $72^{\circ} \mathrm{C}$ for $4 \mathrm{~min}$. Sterile water was used as a negative control for two primer pairs. PCR products were run on an agarose gel for $45 \mathrm{~min}$ at $100 \mathrm{~V}$, as described previously. The entire experiment was repeated once.

Pathogenicity on onion. To confirm pathogenicity on onion, a known $P$. ananatis strain from onion (PNA 97-1) (Gitaitis and Gay 1997), along with test strains PNA 03-3 and PNA 14-12, were grown overnight as described above and inoculum was adjusted to an optical density of 0.3 at $600 \mathrm{~nm}$ (approximately $1 \times 10^{8} \mathrm{CFU} / \mathrm{ml}$ using a spectrophotometer (Spectronic 20; Bausch and Lomb, Rochester, NY). Onion seedlings (cultivar Century) were established in plastic pots ( 10 by $8 \mathrm{~cm}$, diameter by height; Hummert International, Earth

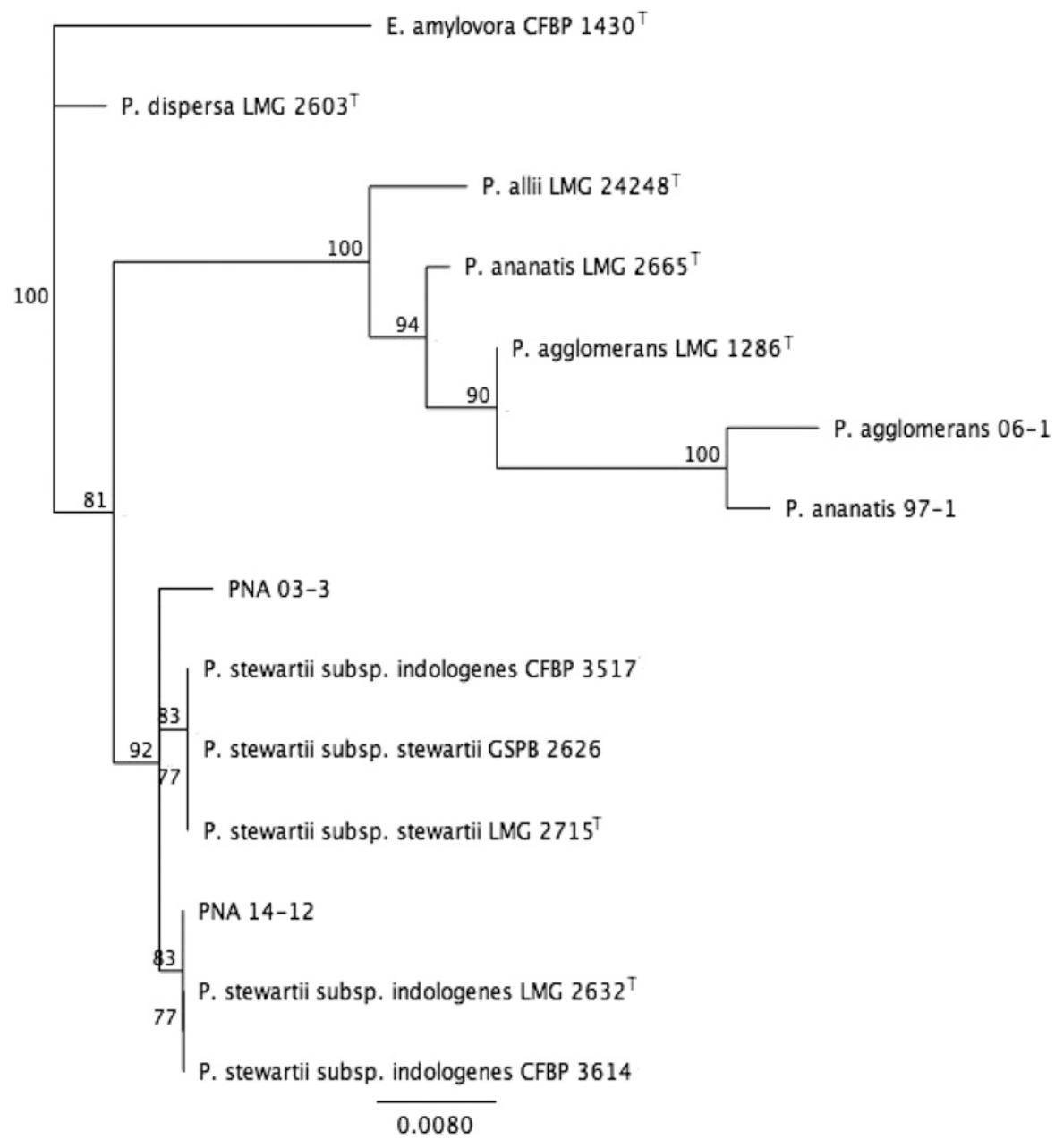

Fig. 1. Maximum-likelihood tree based on the Tamura-Nei model of Pantoea strains derived from partial $16 \mathrm{~S}$ ribosomal RNA sequences. Bootstrap values are based on 1,000 repetitions and values greater than $50 \%$ are shown. Erwinia amylovora CFBP $1430^{\top}$ was used as an outgroup. Superscript "T" denotes type strain of the species. 
City, MO) containing commercial potting mix. The seedlings $(n=5$ seedlings/strain tested) were kept in greenhouse and maintained at 25 to $28^{\circ} \mathrm{C}$ and 80 to $90 \%$ relative humidity with a photoperiod of $12 \mathrm{~h}$ of light and $12 \mathrm{~h}$ of darkness. Three-month-old plants were inoculated by cutting the central leaf $1 \mathrm{~cm}$ from the apex with a sterile pair of scissors, as described earlier (Dutta et al. 2014, 2016). Briefly, using a micropipette, a $10-\mu l$ drop of bacterial suspension was placed at the cut end of the leaf. Seedlings were incubated for 3 days postinoculation (dpi) and were scored for center rot foliar symptoms (white streaking and necrosis of foliage). Seedlings inoculated with $0.1 \mathrm{M}$ phosphate-buffered saline (PBS) served as a negative control.

Additionally, strains were assayed for their ability to cause symptoms on bulbs (cv. Century), as described previously by Schroeder and $\mathrm{du}$ Toit (2010). Prior to inoculation, tunic layers around the bulb were removed and bulbs were surface sterilized with $70 \%$ ethanol. A 50- $\mu$ l aliquot of inoculum was injected into the shoulder region of the bulb ( $n=5$ bulbs/strain) using a syringe and 22-gauge needle. The needle was sterilized between replications and separate syringes and needles were used for each strain. The test strains (PNA 03-3 and PNA 14-12) along with a positive control (PNA 97-1) were used. Bulbs inoculated with $0.1 \mathrm{M}$ PBS served as a negative control. After $3 \mathrm{dpi}$, onion bulbs were cut open and evaluated for symptom expression (rotting and liquefaction). Two independent experiments were conducted for both foliar and bulb assays. Bulbs inoculated with $0.1 \mathrm{M}$ PBS served as a negative control. Seedlings and onion bulbs displaying putative center rot symptoms on respective tissues in the above experiments were sampled for pathogen isolation and identification as described earlier for $P$. ananatis (Dutta et al. 2016; Stumpf et al. 2017). Isolation of pathogens and further identification as $P$. stewartii subsp. indologenes on seedlings and onion bulbs were conducted using subspecies-specific primers, as described above (Gehring et al. 2014).
Pathogenicity on pearl millet. Pearl millet cultivar Tifgrain 102 was established in a greenhouse in the same manner as onion seedlings described above. Inoculum from bacterial suspensions of $P$. stewartii subsp. indologenes LMG $2632^{\mathrm{T}}$ and test strains PNA 03-3 and PNA 14-12 was grown and prepared as previously described. Three-week-old plants were used for inoculation. A syringe was used to infect healthy appearing leaves ( $n=3$ leaves/strain) on the abaxial surface with $0.5 \mathrm{ml}$ of inoculum $\left(1 \times 10^{8} \mathrm{CFU} / \mathrm{ml}\right)$. PBS was used as a negative control. Seedlings with symptoms on foliage were sampled for pathogen isolation and identification, as described earlier for $P$. ananatis and $P$. stewartii subsp. indologenes. Five plants were used in a single experiment and the experiment was repeated once.

\section{Results}

16S rRNA amplification and sequencing. An ML tree was constructed from 16S rRNA sequences of type strains of Pantoea spp. along with two tested strains (PNA 03-3 and PNA 14-12). Erwinia amylovora CFBP 1430 served as an outgroup. Strains PNA 03-3 and PNA 14-12 formed a distinct cluster with the type strains of $P$. stewartii subsp. indologenes and $P$. stewartii subsp. stewartii with a bootstrap value of 92 (Fig. 1). These strains also clustered separately from the type strains of $P$. ananatis, P. allii, P. agglomerans, and P. dispersa (Fig. 1).

MLSA. Four housekeeping genes from Pantoea spp. were sequenced and concatenated to form a phylogenetic tree where $E$. amylovora CFBP $1430^{\mathrm{T}}$ served as an outgroup (Fig. 2). P. dispersa $\mathrm{LMG} 2603^{\mathrm{T}}$ did not cluster closely with any of the strains in this study. As observed in the 16S rRNA phylogenetic tree, PNA 03-3 and PNA 14-12 formed a distinct cluster with the type strains of $P$. stewartii subsp. indologenes and P. stewartii subsp. stewartii, with bootstrap value of 100 (Fig. 2). These strains also clustered separately from the types strains of $P$. ananatis, $P$. allii, $P$. agglomerans, and $P$. dispersa (Fig. 2).

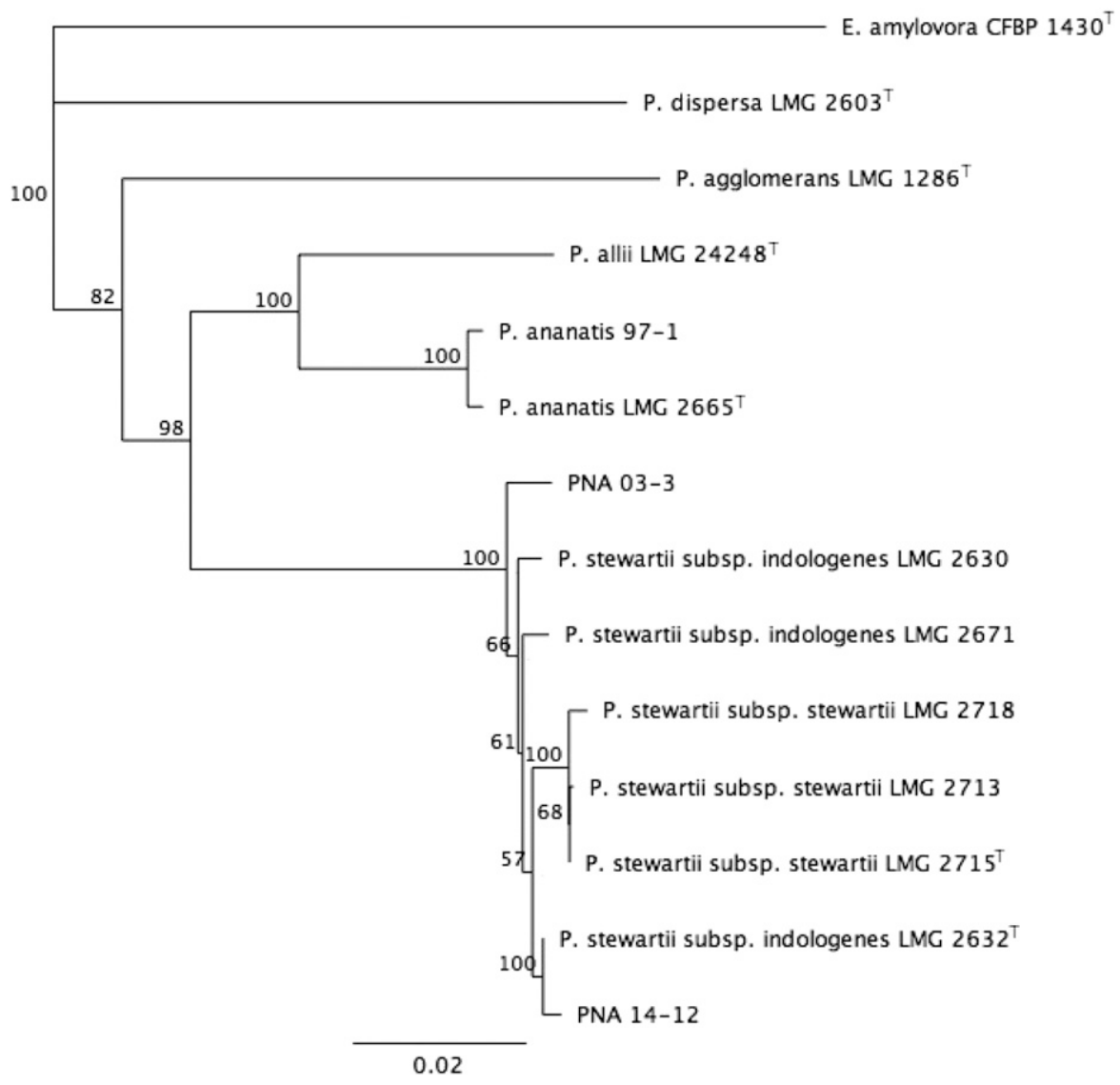

Fig. 2. Maximum-likelihood tree based on the Tamura-Nei model of Pantoea strains derived from concatenation of four housekeeping genes (atpD, gyrB, infB, and rpoB). Bootstrap values are based on 1,000 repetitions and values greater than $50 \%$ are shown. Erwinia amylovora CFBP $1430^{\top}$ was used as an outgroup. Superscript " $T$ " denotes type strain of the species. 
Indole test. As expected, the type strain of $P$. stewartii subsp. indologenes LMG $2632^{\mathrm{T}}$ produced a positive reaction by producing a purple color change on DrySlide indole cards. The strains PNA 03-3 and PNA 14-12 also produced a purple color change on indole cards. The type strain of $P$. stewartii subsp. stewartii LMG $2715^{\mathrm{T}} \mathrm{did}$ not produce a color change.

P. stewartii subsp. indologenes-specific PCR. The type strain of P. stewartii subsp. indologenes LMG $2632^{\mathrm{T}}$ was amplified using both galE- and recA-based primer pairs, with amplicon sizes of 267 and $422 \mathrm{bp}$, respectively. Amplifications with these primer pairs were also observed for the strains PNA 03-3 and PNA 14-12, with expected band sizes of $267 \mathrm{bp}(\mathrm{galE})$ and $422 \mathrm{bp}(\mathrm{recA})$, respectively. Amplifications were not observed for the negative controls and also for none of the tested P. stewartii subsp. stewartii strains (PSS 90-1 and DS 203), including type strain LMG $2715^{\mathrm{T}}$ (Fig. 3).

Pathogenicity on onion. In total, $100 \%$ of the seedlings whose foliage was inoculated with $P$. ananatis $97-1$ displayed typical foliar center rot symptoms (white streak and tissue necrosis) at 3 dpi. Also, all seedlings inoculated with PNA 03-3 and PNA 14-12 displayed symptoms similar to those above at 3 dpi. The severity of symptoms with PNA 03-3 and PNA 14-12 was similar to that of symptoms caused by PNA 97-1 because the mean lesion lengths were around 4 to $4.5 \mathrm{~cm}$ for all

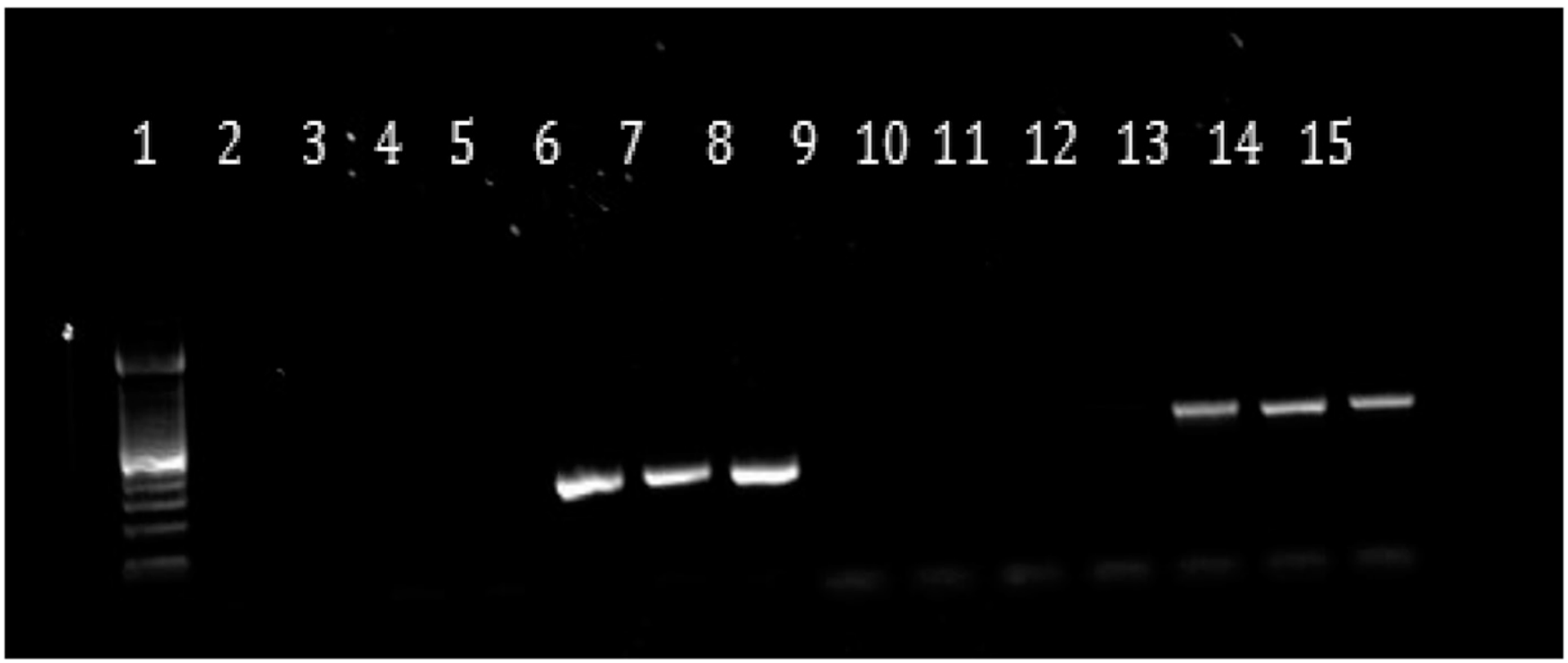

Fig. 3. Pantoea stewartii subsp. indologenes-specific polymerase chain reaction (PCR) assay. Primers based on single-nucleotide polymorphism in galE and recA genes were utilized in stepdown PCR. The lanes in the gel image denote the following: lane 1, 100-bp ladder (New England Biolabs); lane 2, negative control (galE); lane 3, P. stewartii subsp. stewartii (PSS 90-1; galE); lane 4, P. stewartii subsp. stewartii (DS203; galE), lane 5, P. stewartii subsp. stewartii (LMG 2715; ; galE); lane 6, P. stewartii subsp. indologenes (LMG $2632^{\top}$; galE); lane 7, P. stewartii subsp. indologenes (PNA 03-3; galE); lane 8, P. stewartii subsp. indologenes (PNA 14-12; galE); lane 9, negative control (recA); lane 10, P. stewartii subsp. stewartii (PSS 90-1; recA); lane 11, P. stewartii subsp. stewartii (DS203; recA), lane 12, P. stewartii subsp. stewartii (LMG 2715'; recA); lane 13, P. stewartii subsp. indologenes (LMG 2632' ${ }^{\top}$ recA), lane 14, P. stewartii subsp. indologenes (PNA 03-3; recA), and lane 15, P. stewartii subsp. indologenes (PNA 14-12; recA).
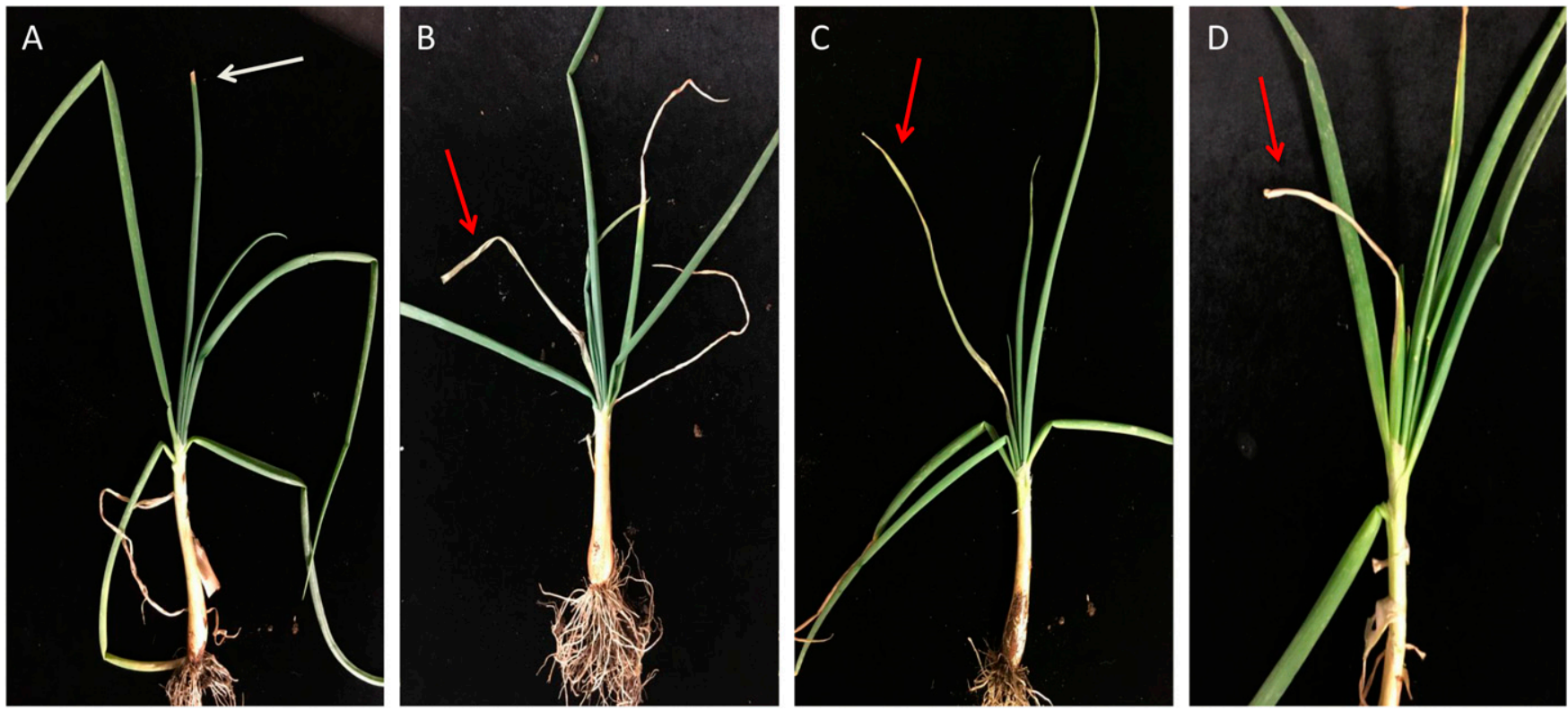

Fig. 4. Center rot symptoms on onion foliage. Onion blades from plants were clipped $1 \mathrm{~cm}$ from the apex and were inoculated by depositing a $10-\mu / \mathrm{drop}\left(1 \times 10^{8} \mathrm{CFU} / \mathrm{ml}\right)$ at the $\mathrm{cut}$ end. A, Phosphate-buffered saline (PBS) (0.1 M); B, Pantoea ananatis 97-1; C, P. stewartii subsp. indologenes (PNA 03-3); and D, P. stewartii subsp. indologenes (PNA 14-12). Symptoms of center rot were observed 3 days after inoculation. Total two experiments were conducted with five replicates per treatment. Arrows in $B$ to $D$ denote necrotic lesions on the inoculated foliage and the arrow in A denotes a leaf inoculated with PBS. 
tested strains. Center rot symptoms were not observed in negative control seedlings (Fig. 4).

Bulbs ( $n=5$ bulbs/strain/experiment) inoculated with $P$. ananatis $97-1$ and $P$. ananatis LMG $2665^{\mathrm{T}}$ exhibited typical center rot symptoms (liquefaction and rotting) at $3 \mathrm{dpi}$. These symptoms were also present in onion bulbs inoculated with PNA 03-3 and PNA 14-12 at 3 dpi. The type strain of $P$. stewartii subsp. indologenes LMG $2632^{\mathrm{T}}$ did not cause liquefaction or rotting of onion bulbs. Bulbs subjected to negative control did not express symptoms (Fig. 5; Supplementary Figure $\mathrm{S} 1)$. Isolates from the infected foliage and bulb tissues were reisolated and reconfirmed as $P$. stewartii subsp. indologenes using a speciesspecific PCR assay, as described above (Gehring et al. 2014). In some instances, other noninoculated foliage in the same plant displayed leafdrying symptoms (Fig. 4B). Isolations were made from the same foliage, which did not result in bacterial colonies on agar medium.

Pathogenicity on pearl millet. White streaks with necrotic lesions were observed with the type strain of $P$. stewartii subsp. indologenes LMG $2632^{\mathrm{T}}$ (positive control) at $5 \mathrm{dpi}$ for all of the replicates in two experiments. In two independent experiments, plants infected with PNA 03-3 and PNA 14-12 strains displayed symptoms as above at 5 dpi. Plants inoculated with PBS (negative control) did not show symptoms on foliage (Fig. 6). Isolates from the infected foliage were reisolated and reconfirmed as $P$. stewartii subsp. indologenes, as described above.

\section{Discussion}

Currently, three known closely related Pantoea spp. (P. ananatis, $P$. agglomerans, and $P$. allii) are associated with center rot of onion. These bacterial species induce similar symptoms on onion such as leaf blight and bulb rot (Brady et al. 2011; Edens et al. 2006; Gitaitis and Gay 1997). Physiological and molecular tests can reliably differentiate these three Pantoea spp. (Delétoile et al. 2009). Apart from various genotypic and physiological assays that can differentiate $P$. agglomerans from $P$. ananatis and $P$. allii, indole production is used as an easy and quick test to differentiate these species. This test relies on the ability of a microorganism to degrade the amino acid

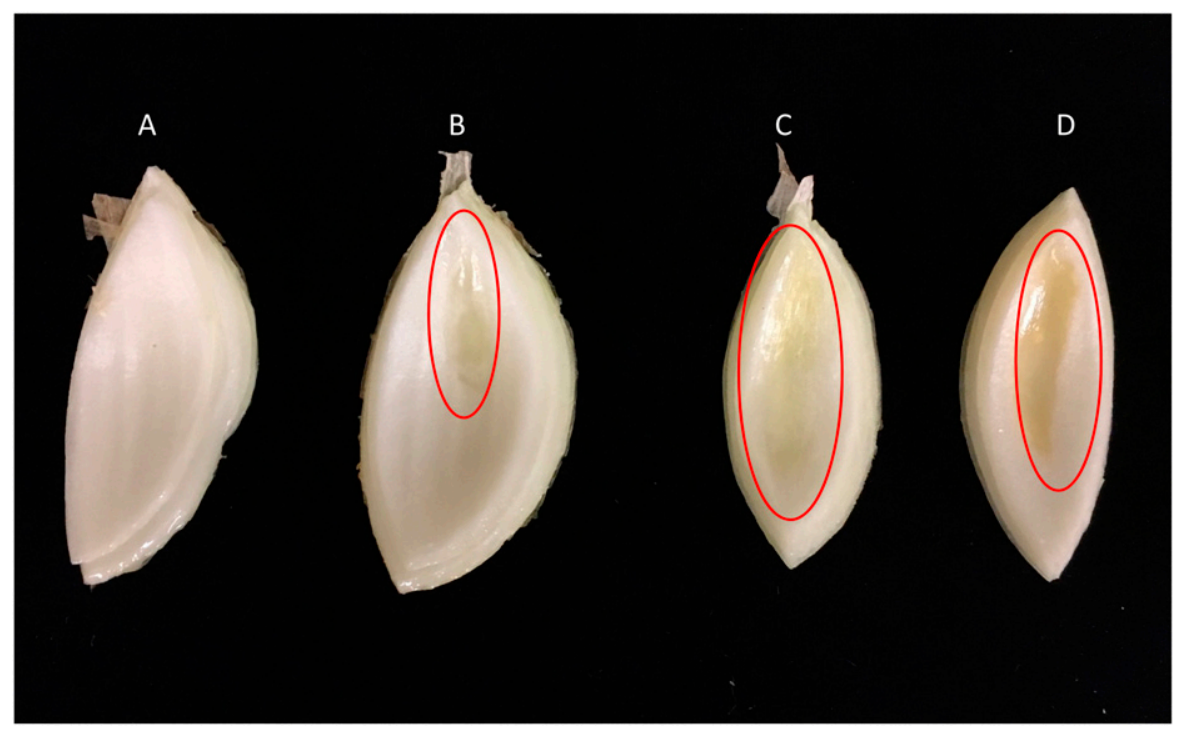

Fig. 5. Center rot symptoms on onion bulbs. Onion bulbs were surface sterilized and inoculated at the shoulder by injecting a $50-\mu /$ drop of bacterial suspension $\left(1 \times 10^{8} \mathrm{CFU} / \mathrm{ml}\right)$ using a syringe. Bulbs were dissected 3 days after inoculation and symptoms (liquefaction and rotting) were observed. A, Phosphate-buffered saline ( $0.1 \mathrm{M})$; B, Pantoea ananatis 97-1; C, P. stewartii subsp. indologenes (PNA 03-3); and D, P. stewartii subsp. indologenes (PNA 14-12). Total two experiments were conducted, with five replicates per treatment. Circled areas denote liquefaction and softening of bulb tissue.
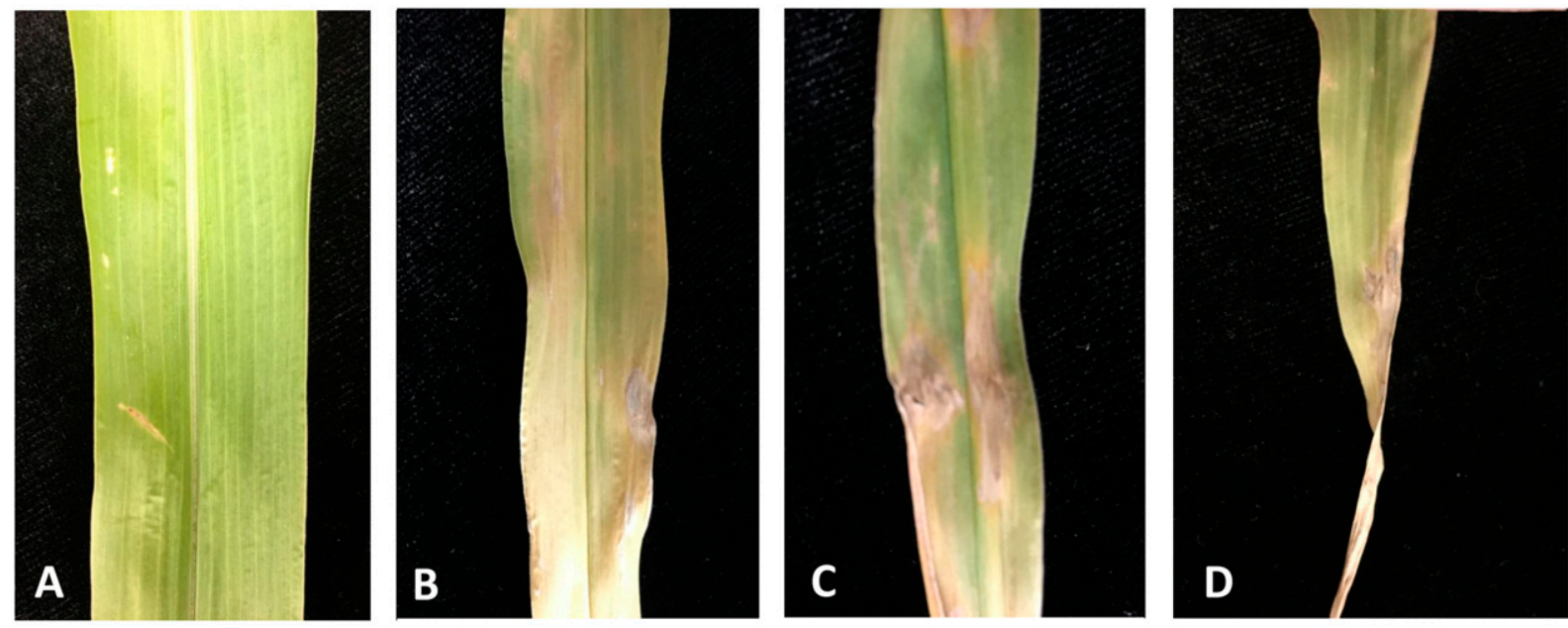

Fig. 6. Pathogenicity assay on Tifgrain 102 pearl millet. Foliage of pearl millet ( 3 weeks old) was infected by infiltrating bacterial suspensions $\left(1 \times 10^{8} \mathrm{CFU} / \mathrm{ml}\right)$ using a syringe. Symptoms (streaking and necrosis) were observed 5 days post inoculation. A, Phosphate-buffered saline $(0.1 \mathrm{M}) ; \mathrm{B}$, Pantoea stewartii subsp. indologenes LMG $2632^{\top}$; C, P. stewartii subsp. indologenes (PNA 03-3); and D, P. stewartii subsp. indologenes (PNA 14-12). Two experiments were conducted, with three repeats per experiment. 
tryptophan and produce indole (Mergaert et al. 1993). Although $P$. agglomerans is indole negative, $P$. ananatis and $P$. allii are indole positive. Moreover, physiologically, $P$. allii can be distinguished from $P$. ananatis and $P$. agglomerans on the basis that the former produces acid from amygdalin and is capable of utilizing adonitol (Brady et al. 2011). The three Pantoea spp. can also be differentiated using molecular assays. Molecular detection assays such as PCR with specific primers are available for $P$. ananatis but not for $P$. agglomerans and P. allii (Asselin et al. 2016; Gitaitis et al. 2002). Hence, researchers routinely rely on sequence analysis of both $16 \mathrm{~S}$ rRNA and housekeeping genes (Hauben et al. 1998; Maiden et al. 1998; Naum et al. 2008). Being a highly conserved gene, 16S rRNA sequences do not reliably differentiate closely related Pantoea spp., including $P$. ananatis, $P$. agglomerans, and $P$. allii. Rather, sequencing of multiple housekeeping genes has been reliably used to differentiate and deduce phylogenetic relationships among closely related Pantoea spp. (Delétoile et al. 2009).

Bacterial strains PNA 03-3 and PNA 14-12 isolated from onion, identified initially as $P$. ananatis, were re-examined using sequencing of 16S rRNA gene and MLSA. These two strains did not cluster with reference strains of $P$. ananatis, $P$. allii, and $P$. agglomerans and exhibited $>99 \%$ sequence similarity to $P$. stewartii subsp. indologenes and $P$. stewartii subsp. stewartii. Rather, they formed a distinct cluster with the type strains of $P$. stewartii subsp. indologenes and $P$. stewartii subsp. stewartii, with bootstrap value more than 92 (Fig. 1). These results indicate that strains PNA 03-3 and PNA 14-12 are closely related to $P$. stewartii subsp. indologenes and $P$. stewartii subsp. stewartii, and distinct from known center-rot-causing Pantoea spp. ( $P$. ananatis, $P$. allii, and $P$. agglomerans).

Indole production has been a reliable biochemical test used to differentiate $P$. stewartii subsp. stewartii from $P$. stewartii subsp. indologenes. It was observed that the type strain of $P$. stewartii subsp. indologenes LMG 2632 ${ }^{\mathrm{T}}$, along with strains PNA 03-3 and PNA 14-12, produced a positive indole reaction whereas $P$. stewartii subsp. stewartii LMG $2715^{\mathrm{T}}$ did not. These observations indicate that strains PNA 03-3 and PNA 14-12 may belong to the subspecies "indologenes" of $P$. stewartii. Further confirmation was achieved by $P$. stewartii subsp. indologenes-specific PCR assays (Gehring et al. 2014). The type strain of $P$. stewartii subsp. indologenes LMG $2632^{\mathrm{T}}$ and strains PNA 03-3 and PNA 14-12 were amplified using galE and recA primer pairs. In contrast, $P$. stewartii subsp. stewartii strains were not amplified by the same primer pairs. These results further confirm that strains PNA 03-3 and PNA 14-12 are not $P$. stewartii subsp. stewartii but, rather, $P$. stewartii subsp. indologenes.

Center rot of onion produces typical leaf blight and bulb rot symptoms on onion. Several researchers have successfully demonstrated methods of conducting pathogenicity assays on onion leaves and bulbs (Carr et al. 2013; Schroeder and du Toit 2010). The strains were used for the pathogenicity assays on onion foliage and onion bulbs. Of the seedlings whose foliage was inoculated with $P$. ananatis $97-1$ along with our strains in question (PNA 03-3 and PNA 14-12), 100\% displayed typical foliar and bulb symptoms at $3 \mathrm{dpi}$. Interestingly, the type strain of $P$. stewartii subsp. indologenes LMG $2632^{\mathrm{T}}$ did not produce any visible foliar and bulb symptoms. These results suggest that the strains PNA 03-3 and PNA 14-12 can potentially be novel $P$. stewartii subsp. indologenes strains capable of producing symptoms on onion. In addition, $P$. stewartii subsp. indologenes $\mathrm{LMG} 2632^{\mathrm{T}}$ and the strains PNA 03-3 and PNA 14-12 were pathogenic on pearl millet, indicating that onion strains responded typically to their described subspecies (Mergaert et al. 1993). Together, the results suggest that these onion strains could potentially represent a new pathovar of $P$. stewartii subsp. indologenes that is pathogenic on both onion and pearl millet. Further detailed pathogenicity assays are required to determine the host range of these onion strains, especially on other Allium spp.

This is the first instance where P. stewartii subsp. indologenes has been identified as a pathogen of onion. Hence, we recommend the inclusion of $P$. stewartii subsp. indologenes as the fourth member in the center rot complex of onion, along with $P$. ananatis, $P$. agglomerans, and $P$. allii. For diagnostic purposes, it is important to assay symptomatic center rot plants for $P$. stewartii subsp. indologenes in addition to $P$. ananatis, $P$. agglomerans, and $P$. allii. Moreover, further research should investigate the vector transmissibility, distribution, prevalence, and epidemiology of this pathogen to determine whether it behaves in a manner similar to other center-rot-causing Pantoea spp. A better understanding of the above biology, epidemiology, and distribution will facilitate better management practices for center rot of onion.

\section{Literature Cited}

Asselin, J. E., Bonasera, J. M., and Beer, S. V. 2016. PCR primers for detection of Pantoea ananatis, Burkholderia spp., and Enterobacter sp. from onion. Plant Dis. 100:836-846.

Brady, C., Cleenwerck, I., Venter, S., Vancanneyt, M., Swings, J., and Coutinho, T. 2008. Phylogeny and identification of Pantoea species associated with plants, humans and the natural environment based on multilocus sequence analysis (MLSA). Syst. Appl. Microbiol. 31:447-460.

Brady, C. L., Goszczynska, T., Venter, S. N., Cleenwerck, I., Vos, P., Gitaitis, R. D., Coutinho, T. A., and de Vos, P. 2011. Pantoea allii sp. nov., isolated from onion plants and seed. Int. J. Syst. Evol. Microbiol. 61:932-937.

Carr, E. A., Zaid, A. M., Bonasera, J. M., Lorbeer, J. W., and Beer, S. V. 2013. Infection of onion leaves by Pantoea ananatis leads to bulb infection. Plant Dis. 97:1524-1528.

Delétoile, A., Decré, D., Courant, S., Passet, V., Audo, J., Grimont, P., Arlet, G., and Brisse, S. 2009. Phylogeny and identification of Pantoea species and typing of Pantoea agglomerans strains by multilocus gene sequencing. J. Clin. Microbiol. 47:300-310.

Dutta, B., Barman, A. K., Srinivasan, R., Avci, U., Ullman, D. E., Langston, D. B., and Gitaitis, R. D. 2014. Transmission of Pantoea ananatis and P. agglomerans, causal agents of center rot of onion (Allium cepa), by onion thrips (Thrips tabaci) through feces. Phytopathology 104:812-819.

Dutta, B., Gitaitis, R., Barman, A., Avci, U., Marasigan, K., and Srinivasan, R. 2016. Interactions between Frankliniella fusca and Pantoea ananatis in the center rot epidemic of onion (Allium cepa). Phytopathology 106:956-962.

Edens, D. G., Gitaitis, R. D., Sanders, F. H., and Nischwitz, C. 2006. First report of Pantoea agglomerans causing a leaf blight and bulb rot of onions in Georgia. Plant Dis. 90:1551.

Gehring, I., Wensing, A., Gernold, M., Wiedemann, W., Coplin, D. L., and Geider, K. 2014. Molecular differentiation of Pantoea stewartii subsp. indologenes from subspecies stewartii and identification of new isolates from maize seeds. J. Appl. Microbiol. 116:1553-1562.

Gitaitis, R., Walcott, R., Culpepper, S., Sanders, H., Zolobowska, L., and Langston, D. 2002. Recovery of Pantoea ananatis, causal agent of center rot of onion, from weeds and crops in Georgia, USA. Crop Prot. 21:983-989.

Gitaitis, R. D., and Gay, J. D. 1997. First report of a leaf blight, seed stalk rot, and bulb decay of onion by Pantoea ananas in Georgia. Plant Dis. 81:1096.

Hattingh, M. J., and Walters, D. F. 1981. Stalk and leaf necrosis of onion caused by Erwinia herbicola. Plant Dis. 65:615-618.

Hauben, L., Moore, E. R., Vauterin, L., Steenackers, M., Mergaert, J., Verdonck, L., and Swings, J. 1998. Phylogenetic position of phytopathogens within the Enterobacteriaceae. Syst. Appl. Microbiol. 21:384-397.

Maiden, M. C., Bygraves, J. A., Feil, E., Morelli, G., Russell, J. E., Urwin, R., Zhang, Q., Zhou, J., Zurth, K., Caugant, D. A., Feavers, I. M., Achtman, M., and Spratt, B. G. 1998. Multilocus sequence typing: A portable approach to the identification of clones within populations of pathogenic microorganisms. Proc. Natl. Acad. Sci. USA 95:3140-3145.

Mergaert, J., Verdonck, L., and Kersters, K. 1993. Transfer of Erwinia ananas (synonym, Erwinia uredovora) and Erwinia stewartii to the genus Pantoea emend. as Pantoea ananas (Serrano 1928) comb. nov. and Pantoea stewartii (Smith 1898) comb. nov., respectively, and description of Pantoea stewartii subsp. indologenes subsp. nov. Int. J. Syst. Bacteriol. 43:162-173.

Naum, M., Brown, E. W., and Mason-Gamer, R. J. 2008. Is 16S rDNA a reliable phylogenetic marker to characterize relationships below the family level in the Enterobacteriaceae? J. Mol. Evol. 66:630-642.

Schroeder, B. K., and du Toit, L. J. 2010. Effects of postharvest onion curing parameters on Enterobacter bulb decay in storage. Plant Dis. 94:1425-1430.

Stumpf, S., Gitaitis, R., Coolong, T., Riner, C., and Dutta, B. 2017. Interaction of onion cultivar and growth stages on incidence of Pantoea ananatis bulb infection. Plant Dis. 101:1616-1620.

Walcott, R. R., Gitaitis, R. D., Castro, A. C., Sanders, F. H., Jr., and Diaz-Perez, J. C. 2002. Natural infestation of onion seed by Pantoea ananatis, causal agent of center rot. Plant Dis. 86:106-111.

Weisburg, W. G., Barns, S. M., Pelletier, D. A., and Lane, D. J. 1991. 16S ribosomal DNA amplification for phylogenetic study. J. Bacteriol. 173:697-703. 